\title{
SYSTEM FOR MEASURING EMITTANCE CHARACTERISTICS OF ION SOURCES
}

\author{
(D)Vitalii I. Voznyi*, (DMykola O. Sayko, (D)Aleksandr G. Ponomarev, DSerhii O. Sadovyi, \\ (i) Oleg V. Alexenko, (D) Ruslan O. Shulipa \\ Institute of Applied Physics NAS of Ukraine \\ 58, Petropavlivska Str., 40000 Sumy, Ukraine \\ *Corresponding Author: vozny56@gmail.com \\ Received April 13, 2020; last revised June 2, 2020; accepted June 8, 2020
}

The article presents the results of the development of a system for measuring emittance characteristics of ion sources studied at the IAP NAS of Ukraine with the aim of obtaining the ion beams with a high brightness. The emittance measurement system is based on the scheme of an electrostatic scanner and consists of two main parts: the scanner, which moves in the direction perpendicular to the beam axis using a stepper motor, and the electronic system of control, processing and data acquisition. The electronic system contains a Raspberry pi 3B microcomputer, precision DAC/ADCs, the high-voltage amplifier of a scanning voltage up to $\pm 500 \mathrm{~V}$ on deflection plates of the scanner and a wide range current integrator. The determination of the emittance consists in measuring the ion beam intensity distribution when the scanner moves along the $x$-coordinate and the electrostatic scanning along the $x^{\prime}$ angle. The obtained two-dimensional data array allows determining the main characteristics of ion beam: geometric $90 \%$ emittance, the root mean square (rms) emittance, the Twiss parameters and phase ellipse of rms emittance, the beam current profile and the angle current density distribution. To test the performance and functionality of the system, the emittance characteristics of the penning type ion source were measured. The working gas was helium, and the beam energy varied within $7-15 \mathrm{keV}$. At $13 \mathrm{keV}$ of beam energy the following emittances of the $\mathrm{He}^{+}$ions beam was obtained: $90 \%$ emittance is $30 \pi \cdot \mathrm{mm} \cdot \mathrm{mrad}$, rms emittance is $8.4 \mathrm{~mm} \cdot \mathrm{mrad}$, and the normalized rms emittance is equal to $0.022 \mathrm{~mm} \cdot \mathrm{mrad}$. The developed system for measuring the emittance of the ion beams is characterized by a short measurement time of 10-15 minutes.

KEYWORDS: ion beam, electrostatic scanner, Gaussian distribution function, RMS emittance, normalized emittance, Twiss parameters, Penning ion source.

One of the main tools for conducting elemental analysis of various materials is accelerator machines that use focused ion beams (FIB). Accelerator FIB-machines are widely used in semiconductor industry, materials science and lithography. For many years the IAP NAS of Ukraine has successfully operated a FIB ion microprobe installation which is part of the Analytical Accelerator Complex based on an electrostatic accelerator with a maximum voltage at a highvoltage terminal of $2 \mathrm{MV}$ [1]. The spatial resolution of the microprobe is about $2 \mu \mathrm{m}$. To increase the spatial resolution and make a transition to the submicron field of investigation, it is necessary to use ion beams with high brightness and, therefore, with the possibly small transverse emittance at a fixed beam current.

In the aim of obtaining high brightness ion beams the research of various ion sources is being conducted at the IAP NAS of Ukraine. A number of high frequency ion sources have been studied: an inductive, a helicon and a multicusp ion source [2], as well as a gas field ion source [3]. One of the important parameters of the ion source is the emittance of an ion beam because it describes the ability of a beam to focus, transport and accelerate. The concept of the phase space of the ion beam and its emittance is widely used in accelerator physics to describe the dynamics of the ion beam.

To measure the emittance of ion sources being studied at the IAP NAS of Ukraine, a new system for measuring the emittance characteristics of ion sources has been designed and manufactured. The system operation is based on the principle of electrostatic sweep scanner [4]. In comparison with other methods of the emittance measurement [5,6] such a scheme allows to develop a more compact measuring system, to perform measurements in a shorter time, and as well to provide better conditions for automation of the process of measuring the beam emittance characteristics. To test the performance of the system and check the functionality of its units, emittance measurements of a penning ion source were carried out.

This paper presents description of the developed emittance measurement system, provides the procedure for calculating the ion beam emittance, and presents the results of emittance measurement of the penning ion source.

\section{ION BEAM EMITTANCE DEFINITION}

The parameters of the ion beam can be well described in terms of the phase space [7-9]. To describe the beam geometry, an orthogonal system of $x, y, z$ coordinates is used in which transverse axes $x$ and $y$ are perpendicular to the beam propagation direction (longitudinal axis $z$ ). Each particle in a beam has six degrees of freedom: three spatial coordinates of the particle's position $(x, y, z)$ and three momentum coordinates $\left(p_{x}, p_{y}, p_{z}\right)$. With a large number of particles $N$, the state of the beam at a certain point in time can be represented by many points with phase density $f\left(x, y, z, p_{x}, p_{y}, p_{z}, t\right)$, which is often approximated by Gauss function. The $N$ particles of a beam in 6-dimensional phase space occupy a certain phase volume which, according to Liouville's theorem, remains constant when the beam 
particles move under the action of conservative forces. If longitudinal motion of the particles is not coupled to transverse motion, the 6-dimensional phase volume can be separated into 2-dimensional longitudinal volume and 4dimensional transverse phase volume. In the case when the longitudinal momentum $p_{z}$ is constant and much larger than the transverse momentum, the ratio $p_{x} / p_{z}\left(\right.$ or $\left.p_{y} / p_{z}\right)$ is equal to the angular divergence $x^{\prime}=d x / d z$ (or $y^{\prime}=d y / d z$ ). And since $p_{z}$ is a constant value, $p_{x}, p_{y}$ can be replaced by $x^{\prime}$ and $x^{\prime}$ respectively, i.e. by the quantities that can be directly observed. If there is no coupling between transverse movements in $x z$ and $y z$ planes, the beam can be described by the distribution of points in two independent planes of the trace space $(x, x)$ and $(y, y)$. In this case the 4-dimensional phase volume can be separated into its components which form two 2-dimensional phase volumes $\Omega_{x}$ and $\Omega_{y}$ in trace space $\left(x, x^{\prime}\right)$ and $(y, y)$, respectively.

The emittance in the $x$-direction is the projection area $A_{x, 90}$ of the phase volume $\Omega_{x, 90}$, containing $90 \%$ of all representative beam particles, divided by $\pi$ :

$$
\varepsilon_{x, 90}=\frac{A_{x, 90}}{\pi}=\frac{1}{\pi} \iint_{\Omega_{x, 90}} d x d x^{\prime}
$$

An analogous definition holds for the emittance in the $y$-direction. For axisymmetric beams: $\varepsilon_{x}=\varepsilon_{y}=\varepsilon[10]$.

The emittance is a constant of the beam motion if the longitudinal velocity of the beam does not change along the optical axis. As the beam accelerates its emittance decreases because the transverse momentum of the particles remains unchanged while the longitudinal momentum increases, resulting in a reduction of $x^{\prime}$. The quantity which remains constant at beam acceleration is the normalized emittance formed by multiplying the emittance by dimensionless relativistic relations $\beta$ and $\gamma$, where $\beta=v / c, \gamma=\left(1-\beta^{2}\right)^{-1 / 2}$. Here $v$ is a particle velocity and $c$ is a light velocity. In the case of non-relativistic beams we get the expression for calculating of the normalized emittance:

$$
\varepsilon_{N}=\beta \gamma \varepsilon=\varepsilon \cdot 4,6 \cdot 10^{-5} \sqrt{E / A},
$$

where $E$ is the kinetic energy of the beam, $\mathrm{eV}, A$ - mass number of an ion.

Along with the geometric interpretation of the emittance as the contour area containing $90 \%$ of all beam particles, there is a statistical approach in which the beam is considered as a statistical array of points in 2-dimensional trace space with the distribution function $f\left(x, x^{\prime}\right)[9,11,12]$. The particles inside the trace space $\left(x, x^{\prime}\right)$ can be considered as a statistical distribution with average values $\langle x\rangle$ and $\left\langle x^{\prime}\right\rangle$. In this case the root mean square (rms) emittance $\varepsilon_{r m s}$ is determined as standard deviations from these average values. The equation of the phase ellipse of rms emittance has the form: $\gamma x^{2}+2 \alpha x x^{\prime}+\beta x^{\prime 2}=\varepsilon_{r m s}$, where $\alpha, \beta$ and $\gamma$ are the Twiss parameters (the Twiss parameters $\beta$ and $\gamma$ are not to be confused with the relativistic relations). At that projections of the equivalent ellipse on the $x$ and $x^{\prime}$ axis are equal to the standard deviations $\sigma_{x}$ and $\sigma_{x^{\prime}}: \sigma_{x}=\sqrt{\beta \varepsilon_{r m s}}, \sigma_{x^{\prime}}=\sqrt{\gamma \varepsilon_{r m s}}, \sigma_{x x^{\prime}}=-\alpha \varepsilon_{r m s}$, where $\sigma_{x}^{2}=\left\langle x^{2}\right\rangle, \sigma_{x^{\prime}}^{2}=\left\langle x^{\prime 2}\right\rangle$ and $\sigma_{x x^{\prime}}=\left\langle x x^{\prime}\right\rangle$ are the second-order moments of the phase distribution function. The Twiss parameters are connected by the relation: $\gamma \beta-\alpha^{2}=1$. By substituting the Twiss parameters into this equation, we obtain the expression for determining the rms emittance:

$$
\varepsilon_{r m s}=\sqrt{\left\langle x^{2}\right\rangle\left\langle x^{\prime 2}\right\rangle-\left\langle x x^{\prime}\right\rangle^{2}}=\sqrt{\sigma_{x}^{2} \sigma_{x^{\prime}}^{2}-\sigma_{x x^{\prime}}^{2}}
$$

\section{EMITTANCE MEASUREMENT SYSTEM}

The work of the emittance measurement system is based on the principle of operation of an electrostatic scanner [4], which is a variation of emittance measurement by two slits method [5]. The system of emittance measurement consists of two main parts: the scanner, which moves in the direction perpendicular to the axis of the beam, and the electronic system of control, processing and data acquisition. The movement of only one entrance slit determines the compactness of the measuring system and the speed of measurements.

The scanner (Fig. 1a) contains the entrance (1) and exit (3) slits extended along the horizontal $y$-axis, two deflecting plates (2), which are supplied with a saw-tooth electric voltage $V$, a Faraday cup (8) for measuring the ion current passed through both the slits. In front of the Faraday cup there is a ring suppressor (4) to inhibit secondary electrons. The scanner is surrounded by a grounded electrostatic shield and moves in the vertical $x$-direction using a stepper motor.

Fig. $1 \mathrm{~b}$ shows a photo of the scanner without an electrostatic shield. The entrance slit (1) and deflecting plates (2) are shown in the figure. The total length of the scanner is $145 \mathrm{~mm}$. The Faraday cup is $10 \mathrm{~mm}$ in inner diameter and $12 \mathrm{~mm}$ in length. 


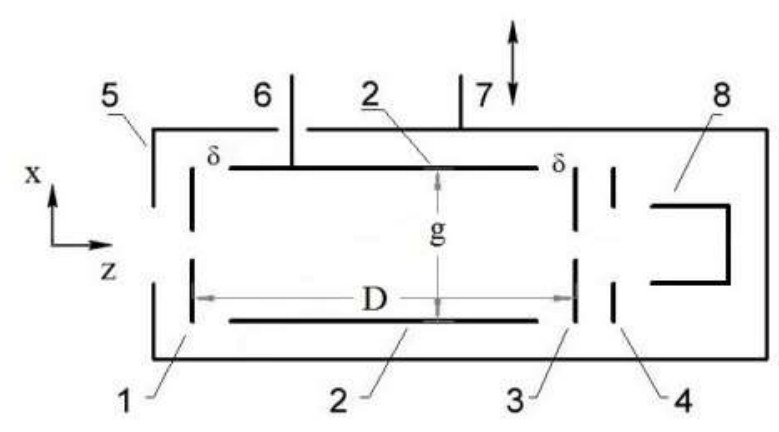

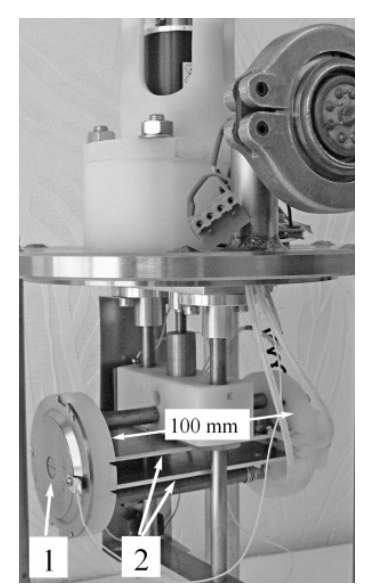

b

Figure 1. a - schematic of the electrostatic scanner: 1 - entrance slit, 2 - deflecting plates, 3 - exit slit, 4 - suppressor, 5 -electrostatic shield, 6 - saw-tooth voltage, 7 - stepper motor, 8 - Faraday cup; b - picture of the scanner (without electrostatic shield), the entrance slit (1) and the deflecting plates (2) are shown.

The determination of the emittance is concluded in measuring the distribution of ion current intensity $Z\left(x, x^{\prime}\right)$ over the $x$-coordinate and $x^{\prime}$ angle. At each $x$-coordinate the ion current passing through both slits is measured with simultaneous linear change in voltage $V$ between the deflecting plates. Thus the distribution of the current intensity over the angle $x^{\prime}$ is determined. Repeating the measurements with a different value of $x$-coordinate, we obtain the complete distribution of the current intensity $Z\left(x, x^{\prime}\right)$.

The relationship between the angle $x^{\prime}$ and the deflecting voltage $V$ is determined by the condition under which an ion with charge $q$ and energy $q U$ passing through the entrance slit at the $x^{\prime}$ angle is deflected and enters the exit slit. In this case angle $x^{\prime}$ is determined by the ratio [2]:

$$
x^{\prime}=V(D-2 \delta) / 4 U g
$$

where $V$ is the potential difference between the deflecting plates, $U$ is the potential difference that the beam passed during acceleration, $D$ is the distance between the slits, $\delta$ is the distance between the deflecting plates and the slits, $g$ is the distance between the deflecting plates. In this design $D=120 \mathrm{~mm}, \delta=10 \mathrm{~mm}, g=10 \mathrm{~mm}$, the width of the entrance and exit slits is $s=200 \mu \mathrm{m}$. The length of the slits in $y$-direction is $12 \mathrm{~mm}$.

The electrostatic scanner which contains both the slits and deflecting plates moves in a vertical plane along the precision guide axes with the help of a stepper motor and ball screw pair passing through the vacuum seal.

In Fig. 2 is shown the control and data acquisition system. The system consists of a microcomputer Raspberry pi 3B (1) by Raspberry Pi Foundation, precision DAC/ADCs, expansion board for Raspberry pi by Waveshare (2), stepper motor driver (3), wide range current integrator (5), high voltage amplifier for generating sweep voltage on deflecting plates (6), stepper motor (8), scanner position switches (9), computer with installed user interface software.

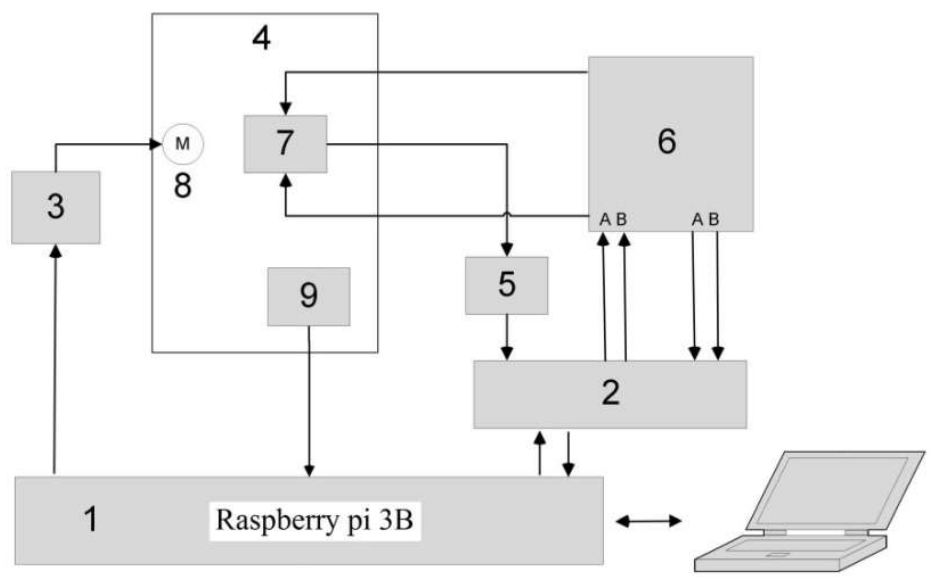

Figure 2. Block diagram of the control and data acquisition system. 1 - microcomputer Raspberry pi 3B, 2 - precision DAC/ADCs, 3 - opto-coupled stepper motor driver, 4 - vacuum chamber, 5 - current integrator, 6 - high voltage amplifier, 7 - electrostatic scanner, 8 - stepper motor, 9 - scanner position switches. 
The microcomputer Raspberry pi 3B has free software installed: Linux based Jessie operating system; Hostapd; wi-fi access point DNSMASQ; server DHCP+DNS; Samba; free implementation of the network protocol SMB/CIFS; Empi program of own development in the high-level language $\mathrm{C}^{++}$.

To form a sweep sawtooth voltage on the deflecting plates a specially developed two-channel high-voltage amplifier (6) is used. Parameters of the voltage amplifier: the gain is 100 , the frequency is $0-1 \mathrm{kHz}$. Each of the amplifier channels converts the input signal in the range of $0-2.5 \mathrm{~V}$, which is supplied from the DAC, into the output voltage from zero to $\pm 250 \mathrm{~V}$. At that voltage on the plates at each moment of time is supported symmetrically opposite to zero. Thus, the potential difference between the plates is adjustable in the range of $\pm 500 \mathrm{~V}$.

The electrostatic scanner moves along the guides using a stepper motor (8). For positioning the scanner, two limit switches of upper and lower positions and a precision zero-position photosensor (9) are used.

The resolution of the scanner along $x$-coordinate is determined by a minimum movement step, which is $4.8 \mu \mathrm{m}$. Typically the movement step is set to 48 or $96 \mu \mathrm{m}$. The range of movement is $0-20 \mathrm{~mm}$.

The angular resolution of the scanner is $1.7 \mathrm{mrad}$. The ratio between the angle $x^{\prime}$ and the scanning voltage $V$ is determined from equation (4) and has the form: $x^{\prime}=2.5 \mathrm{~V} / \mathrm{U}$. At the maximum value of deflecting voltage $V= \pm 500 \mathrm{~V}$ and the beam energy $U=10 \mathrm{kV}$ we obtain the maximum value of the angle $x^{\prime}= \pm 125 \mathrm{mrad}$.

\section{EMITTANCE MEASUREMENT PROCEDURE}

The measured two-dimensional array of ion beam intensity values $Z\left(x, x^{\prime}\right)$ is the distribution of the ion beam current density in the $x$ - $x^{\prime}$ phase plane. The number of cells of the matrix $Z(x, x)$ can vary, and is usually equal to $153 \times 201$ with cell size $\Delta x=0.098 \mathrm{~mm}$ in $x$-coordinate and $\Delta x^{\prime}=0.385 \mathrm{mrad}$ in $x^{\prime}$ angle. The unit of measurement of the array elements $Z\left(x, x^{\prime}\right)$ is $\mathrm{nA} /(\mathrm{mm} \cdot \mathrm{mrad})$.

The measured array of intensity $Z\left(x, x^{\prime}\right)$ enables to determine the main characteristics of the ion beam: the geometric emittance $\varepsilon_{90}$, the rms emittance $\varepsilon_{r m s}$, the Twiss parameters and the phase ellipse of rms emittance, the distribution of current density over the $x$-coordinate (a beam current profile) and the current density distribution over the angle. The total beam current $I$ is proportional to the sum of array values $Z(x, x)$ over all the coordinates $x$ and angles $x^{\prime}: I \propto \sum_{x} \sum_{x^{\prime}} Z\left(x, x^{\prime}\right)$.

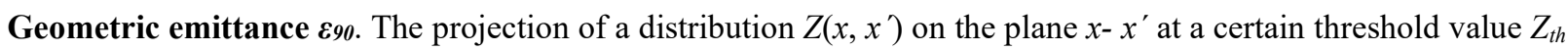
gives emittance diagram, the area of which divided by $\pi$ is the emittance of a beam. The threshold value $Z_{t h}$ is determined as follows: a certain value of $Z_{t h}$ is set and the elements of matrix $Z(x, x)$ whose values are less than $Z_{t h}$ are zeroed. As a result matrix $M(x, x)$ is obtained. In the process the condition is checked to ensure that: $\sum_{x} \sum_{x^{\prime}} M\left(x, x^{\prime}\right)=0,9 \cdot \sum_{x} \sum_{x^{\prime}} Z\left(x, x^{\prime}\right)$. In the result the projection of the matrix $M(x, x)$ onto the $x-x^{\prime}$ plane forms a contour containing $90 \%$ of all beam particles. The area of this contour divided by $\pi$ is the emittance $\varepsilon 90$. The unit of measurement of the emittance is $\mathrm{m} \cdot \mathrm{rad}$ or usually $\mathrm{mm} \cdot \mathrm{mrad}$. The symbol $\pi$ is included in the emittance unit of measurement to indicate that the emittance was defined as the area divided by $\pi$.

RMS emittance $\varepsilon_{r m s}$. The rms emittance is determined from the expression (3). The first order moments $\langle x\rangle,\left\langle x^{\prime}\right\rangle$ and the second order moments $\sigma_{x}^{2}, \sigma_{x^{\prime}}^{2}$ and $\sigma_{x x^{\prime}}$ are calculated from the relations:

$$
\begin{aligned}
& \langle x\rangle=\frac{\sum_{x} \sum_{x^{\prime}} x \cdot Z\left(x, x^{\prime}\right)}{\sum_{x} \sum_{x^{\prime}} Z\left(x, x^{\prime}\right)},\left\langle x^{\prime}\right\rangle=\frac{\sum_{x} \sum_{x^{\prime}} x^{\prime} \cdot Z\left(x, x^{\prime}\right)}{\sum_{x} \sum_{x^{\prime}} Z\left(x, x^{\prime}\right)}, \sigma_{x}^{2}=\left\langle x^{2}\right\rangle=\frac{\sum_{x} \sum_{x^{\prime}}(x-\langle x\rangle)^{2} Z\left(x, x^{\prime}\right)}{\sum_{x} \sum_{x^{\prime}} Z\left(x, x^{\prime}\right)}, \\
& \sigma_{x^{\prime}}^{2}=\left\langle x^{\prime 2}\right\rangle=\frac{\sum_{x} \sum_{x^{\prime}}\left(x^{\prime}-\left\langle x^{\prime}\right\rangle\right)^{2} Z\left(x, x^{\prime}\right)}{\sum_{x} \sum_{x^{\prime}} Z\left(x, x^{\prime}\right)}, \quad \sigma_{x x^{\prime}}=\left\langle x x^{\prime}\right\rangle=\frac{\sum_{x} \sum_{x^{\prime}}(x-\langle x\rangle)\left(x^{\prime}-\left\langle x^{\prime}\right\rangle\right) Z\left(x, x^{\prime}\right)}{\sum_{x} \sum_{x^{\prime}} Z\left(x, x^{\prime}\right)} .
\end{aligned}
$$

The Twiss parameters and phase ellipse. The Twiss parameters are determined from the expressions:

$$
\beta=\frac{\sigma_{x}^{2}}{\varepsilon_{r m s}}, \gamma=\frac{\sigma_{x^{\prime}}^{2}}{\varepsilon_{r m s}}, \alpha=-\frac{\sigma_{x x^{\prime}}}{\varepsilon_{r m s}} .
$$

They define the phase ellipse equation, which taking into account the average values $\langle x\rangle$ and $\left\langle x^{\prime}\right\rangle$ has the form:

$$
\gamma(x-\langle x\rangle)^{2}+2 \alpha(x-\langle x\rangle)\left(x^{\prime}-\left\langle x^{\prime}\right\rangle\right)+\beta\left(x^{\prime}-\left\langle x^{\prime}\right\rangle\right)^{2}=\varepsilon_{r m s} .
$$

Beam current profile. The distribution of current density over $x$-coordinate is obtained by summing the elements 
of the array $Z\left(x, x^{\prime}\right)$ over all the values of the $x^{\prime}$ angle for each $x$ coordinate:

$$
Z(x)=\sum_{x^{\prime}} Z\left(x, x^{\prime}\right), \mathrm{nA} / \mathrm{mm} .
$$

The distribution of current density over the angle. A similar way can be done in determining the current density distribution of the ion beam over the angle. Summing up the elements of the array $Z(x, x)$ over all the values of the $x$-coordinate for each value of $x^{\prime}$ angle we obtain:

$$
Z\left(x^{\prime}\right)=\sum_{x} Z\left(x, x^{\prime}\right), \mathrm{nA} / \mathrm{mrad}
$$

\section{RESULTS OF MEASUREMENTS}

To test the performance and functionality of the emittance measurement system, the emittance characteristics of the penning ion source were measured. The ion source is a penning type ion source with a cold cathode [13]. It is an economical ion source and it does not create electromagnetic interference disturbing the operation of electronic equipment. The power consumption of the source is about $5 \mathrm{~W}$, the full ion current is $5-20 \mu \mathrm{A}$. The source consists of a cylindrical anode, a cathode with an aperture for beam extraction and an anticathode. The inner diameter of the anode is $25 \mathrm{~mm}$, the distance between a cathode and anticathode is $43 \mathrm{~mm}$ and the diameter of the extraction aperture is $0.8 \mathrm{~mm}$. A magnetic system consisting of 4 ring ferrite magnets is located coaxial to the anode. The longitudinal component of magnetic induction on the discharge axis is equal to $0.085-0.09 \mathrm{~T}$, the voltage between an anode and cathode is $5 \mathrm{kV}$, the discharge current is $I_{d}=0.22 \mathrm{~mA}$.

The emittance of the penning ion source was measured at a stand for studying the ion sources parameters. The scheme of the experimental setup is shown in Fig. 3.

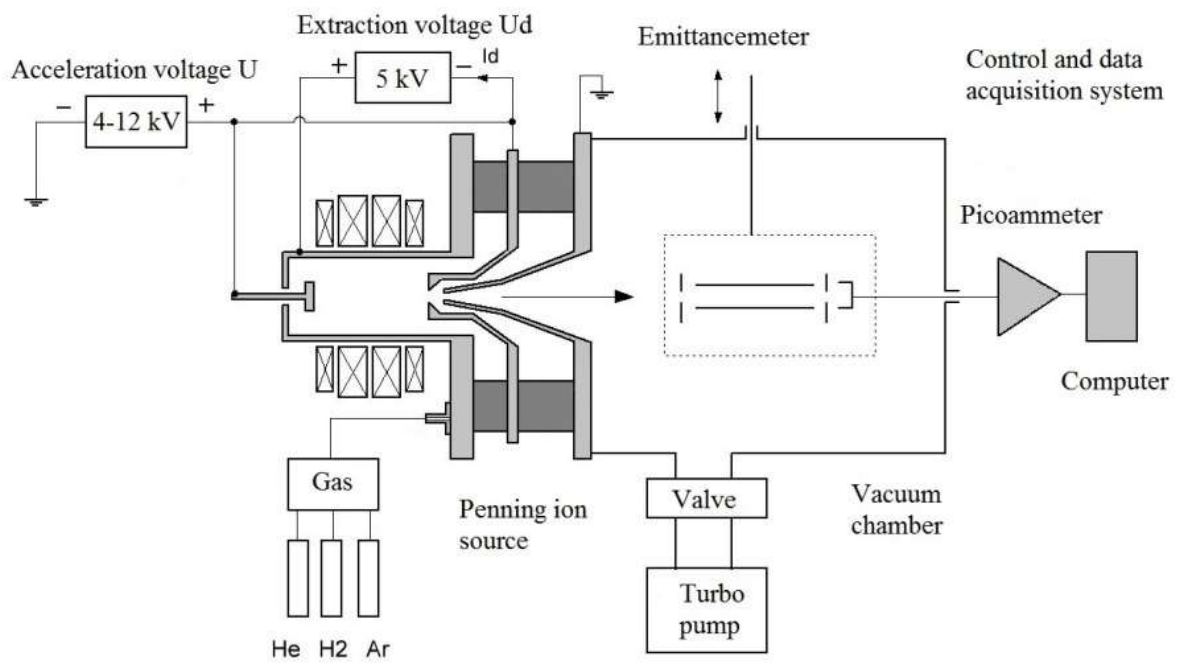

Figure 3. Experimental setup for emittance measurement of a penning ion source.

The ion beam energy varied within $E=7-15 \mathrm{keV}$, the working gas was helium. While measuring the emittancemeter was located at a distance of $40 \mathrm{~mm}$ from the base of the accelerating electrode of the source.

In Fig. $4 \mathrm{a}$ is shown a 3-dimensional surface of the current intensity distribution $Z\left(x, x^{\prime}\right)$ at the energy $E=13 \mathrm{keV}$. By its form the current intensity distribution $Z\left(x, x^{\prime}\right)$ is close to Gaussian distribution function. In Fig. $4 \mathrm{~b}$ the 2dimensional emittance diagram is presented which is a projection of the $Z(x, x)$ array on $x-x^{\prime}$ plane. The emittance diagram depicts the contour of the geometric emittance which contains $90 \%$ of all the beam particles. At the beam energy of $E=13 \mathrm{keV}$ the geometrical emittance equals $\varepsilon_{9_{0}}=30 \pi \cdot \mathrm{mm} \cdot \mathrm{mrad}$.

The rms emittance is determined from equation (3). With increasing beam energy in the range $E=9-15 \mathrm{keV} \mathrm{rms}$ emittance decreases from $10 \mathrm{~mm} \cdot \mathrm{mrad}$ to $8.3 \mathrm{~mm} \cdot \mathrm{mrad}$. At the energy of $E=13 \mathrm{keV} \mathrm{rms}$ emittance is equal to $\varepsilon_{r m s}=8.4 \mathrm{~mm} \cdot \mathrm{mrad}$.

Normalized rms emittance is determined from equation (2) and equals $\varepsilon_{N, r m s}=0.022 \mathrm{~mm} \cdot \mathrm{mrad}$. This value of emittance is conserved when the beam energy changes.

The moments of the first and second orders as well as the Twiss parameters for ion beam with energy $E=13 \mathrm{keV}$ have the following values: $\langle x\rangle=8.4 \mathrm{~mm},\left\langle x^{\prime}\right\rangle=14.5 \mathrm{mrad}, \sigma_{x}=1.9 \mathrm{~mm}, \sigma_{x^{\prime}}=15.4 \mathrm{mrad}, \sigma_{x x^{\prime}}=28.2 \mathrm{~mm} \cdot \mathrm{mrad}$, $\gamma=28.4 \mathrm{mrad} / \mathrm{mm}, \alpha=-3.35, \beta=0.43 \mathrm{~mm} / \mathrm{mrad}$. These parameters define equation (7) of the phase ellipse of rms 
emittance which has the form: $28.4(x-8.4)^{2}-6.7(x-8.4)\left(x^{\prime}-14.5\right)+0.43\left(x^{\prime}-14.5\right)^{2}=8.4$. The graph of the phase ellipse is shown in Fig. 5a.

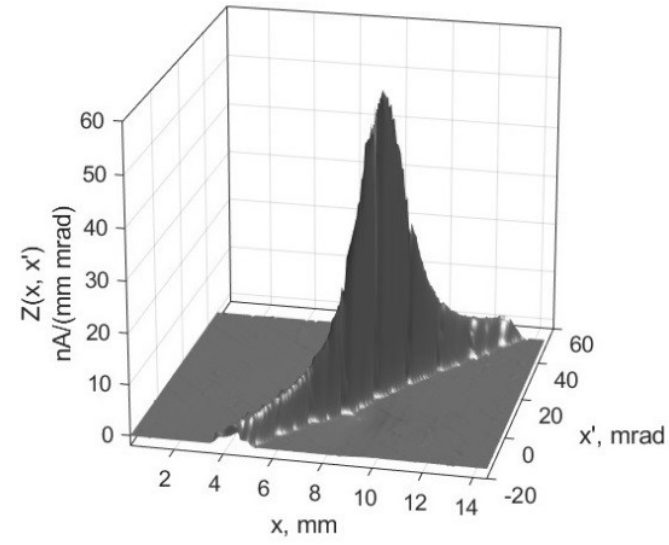

a

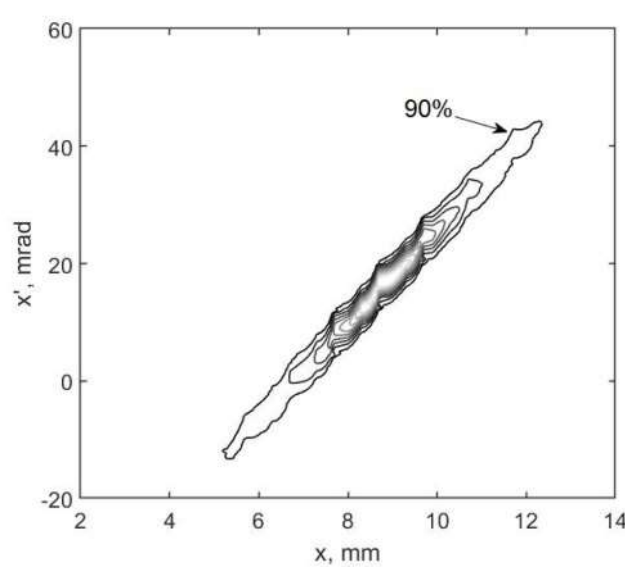

$\mathrm{b}$

Figure 4. $\mathrm{a}-3 \mathrm{D}$ surface of the current intensity distribution $Z(x, x)$ of $\mathrm{He}^{+}$ion beam with energy $E=13 \mathrm{keV}, \mathrm{b}-$ diagram of the geometric $90 \%$ emittance of helium ion beam in the $x$ - $x^{\prime}$ plane.

The inclination angle $\theta$ of the phase ellipse to axis $x$ is given by the expression [7]: $\operatorname{tg} 2 \theta=\frac{2 \sigma_{x x^{\prime}}}{\sigma_{x}^{2}-\sigma_{x^{\prime}}^{2}}$. Considering the scale of Fig. 5a this ratio looks like: $\operatorname{tg} 2 \theta=2 \sigma_{x x^{\prime}} / m n\left(\sigma_{x}^{2} / m-\sigma_{x^{\prime}}^{2} / n\right)$, where $m=12 \mathrm{~mm}, n=80 \mathrm{mrad}$. If $\theta<0$ then angle $90^{\circ}$ must be added to its value. As a result the inclination angle is equal to $\theta=51^{\circ}$.

The position and shape of the ellipse of rms emittance $\varepsilon_{r m s}$ in Fig. 5a coincides well with the graph of the geometric emittance $\varepsilon_{90}$ (Fig. 4b). This indicates that calculations of the emittance by geometric and statistical methods are in good agreement.

In Fig. $5 \mathrm{~b}$ shows the ion beam current profile calculated from expression (8).

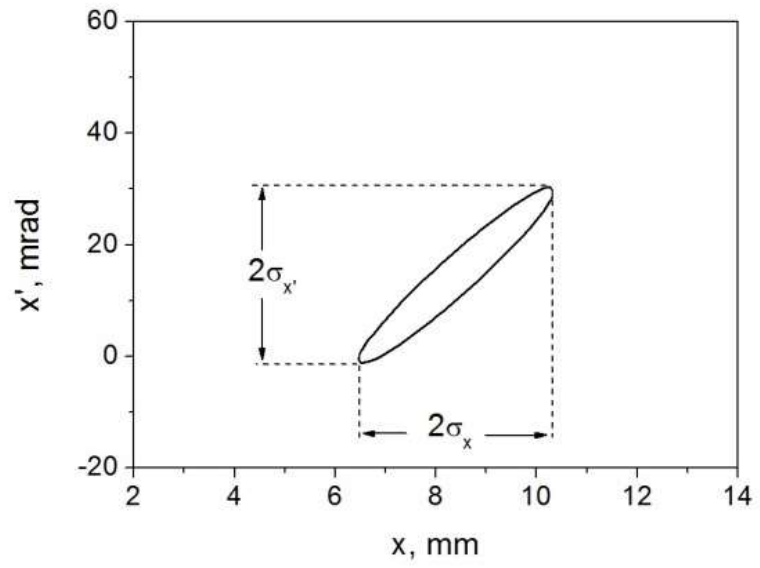

$\mathrm{a}$

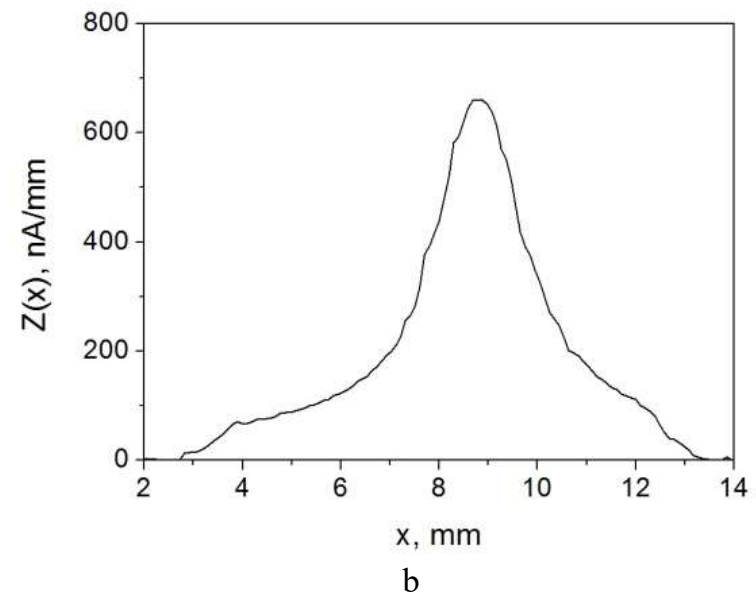

$\mathrm{b}$

Figure 5. a - phase ellipse of rms emittance, $b$ - ion beam current profile.

Since the Twiss parameter $\alpha<0$, the beam is diverging. The divergence angle is equal to $2 \sigma_{x^{\prime}}=30.8 \mathrm{mrad}$, and the beam envelope width (beam diameter) is $2 \sigma_{x}=3.8 \mathrm{~mm}$.

\section{CONCLUSION}

The study of ion sources is being conducted at the IAP NAS of Ukraine in order to obtain the high brightness ion beams. High brightness beams of charged particles are necessary for use in various FIB-accelerator machines, in nanotechnology, and ion nanolithography. To measure the emittance of ion beams, a system for measuring emittance characteristics of ion sources has been designed and manufactured.

The measuring system consists of the electrostatic scanner moving in the direction perpendicular to the beam axis, and the electronic system of control and data acquisition, which contains a Raspberry microcomputer, precision DAC/ADCs, a high-voltage amplifier for a scanning saw-tooth voltage up to $\pm 500 \mathrm{~V}$, and a wide-band current integrator. 
The performance of measurement system was checked when measuring the emittance of a penning ion source. The working gas was helium, the energy of the ion beam varied within 7-15 keV. The beam emittance was determined both geometrically, measuring the emittance $\varepsilon_{90}$ of the phase contour containing $90 \%$ of beam particles, and statistically, determining the rms emittance $\varepsilon_{r m s}$. At the beam energy $E=13 \mathrm{keV}$ the following values of the emittance are obtained: $\varepsilon_{90}=30 \pi \cdot \mathrm{mm} \cdot \mathrm{mrad}, \varepsilon_{r m s}=8.4 \mathrm{~mm} \cdot \mathrm{mrad}$, the normalized $\mathrm{rms}$ emittance is equal to $\varepsilon_{N, r m s}=0.022 \mathrm{~mm} \cdot \mathrm{mrad}$. The Twiss parameters that describe the phase ellipse of rms emittance are determined, and the ion beam profile, the divergence angle and the beam envelope width are measured. The first moments $\langle x\rangle$ and $\left\langle x^{\prime}\right\rangle$ determine the position and direction of the ion beam propagation. These data can be used to correct the position of the beam during its transportation.

The obtained emittance of $30 \pi \cdot \mathrm{mm} \cdot \mathrm{mrad}$ (or $3.4 \pi \cdot \mathrm{mm} \cdot \mathrm{mrad} \cdot(\mathrm{MeV})^{1 / 2}$ in terms of the ion beam energy) has a value typical for penning's ion sources with cold cathode. In particular the penning ion source with cold cathode from High Voltage Engineering Europa B.V. (HSEE) has the emittance of $3 \pi \cdot \mathrm{mm} \cdot \mathrm{mrad} \cdot(\mathrm{MeV})^{1 / 2}[14]$.

This emittance measurement system is characterized by relatively small dimensions and short measurement time of 10-15 min., which are due to the movement of only one entrance slit and the control of one stepper motor. It distinguishes the developed system favorably from emittancemeters that use the movement of two slits.

The system for measuring emittance characteristics is designed for the stand researches of ion sources with the beam energy of tens $\mathrm{keV}$. At the same time, the measuring system can be used in the studies on optimization of beam transport systems at the output of the small- sized electrostatic accelerators used for elemental analysis of materials with ion beams.

This work was carried out within the framework of the project No. 0118U004435 of the Scientific Instrument Engineering Program of NAS of Ukraine for 2017-2019 "Automated emittancemeter for measuring the ion beam brightness".

\section{ORCID IDs}

(D)Vitalii I. Voznyi, https://orcid.org/0000-0002-9979-639X; DMkola O. Sayko, https://orcid.org/0000-0002-3393-4753;

(D)Aleksandr G. Ponomarev, https://orcid.org/0000-0002-4517-5635; Derhii O. Sadovyi, https://orcid.org/0000-0002-9427-1033;

DOleg V. Alexenko, https://orcid.org/0000-0002-4310-0920; DRuslan O. Shulipa, https://orcid.org/0000-0002-9571-3059.

\section{REFERENCES}

[1] D.V. Magilin, A.G. Ponomarev, V.A. Rebrov, N.A. Sayko, K.I. Melnik, V.I. Miroshnichenko, and V.Y. Storizhko, Nucl. Instr. and Meth. B. 267, 2046-2049 (2009). https://doi.org/10.1016/j.nimb.2009.03.015.

[2] V. Voznyi, V. Miroshnichenko, S. Mordyk, D. Shulha, V. Storizhko, and V. Tokman, J. Nano Electron. Phys. 5(4), 04060 (2013), https://jnep.sumdu.edu.ua/download/numbers/2013/4/articles/en/jnep_2013_V5_04060.pdf.

[3] V.I. Vozny, V.Yu. Storizhko, V.I. Miroshnichenko, V.V. Tokman, Ye.A. Mironets, and Ye.O. Batura. Nauka innov. 6(5), $72-76$ (2010). https://doi.org/10.15407/scin6.05.072, (in Russian)

[4] P.W. Allison, J.D. Sherman, and D.B. Holtkamp, IEEE Trans. Nucl. Sci. 30(4), 2204-2206 (1983), https://doi.org/10.1109/TNS.1983.4332762.

[5] C. Lejeune, and J. Aubert, in: Applied Charged Particle Optics, Part A, edited by A.Septier, (Academic Press, New York, 1980), pp.159-259.

[6] V.V. Kuz'menko, V.G. Bogdalin, and V.M. Pistrjak. Problems of Atomic Science and Technology. Series: General and Nuclear Physics, 2(12), 74-77 (1980). (in Russian)

[7] J. Buon, in: CAS-CERN Accelerator School: $5^{\text {th }}$ General Accelerator Physics Course, (1992), pp.89-116. http://dx.doi.org/10.5170/CERN-1994-001.

[8] M. Reiser, Theory and Design of Charged Particle Beams, $2^{\text {nd }}$ ed. (Wiley-VCH, Weinheim, 2008), pp. 51-61, pp. 128-134, pp. 320-326. http://dx.doi.org/10.1002/9783527622047.

[9] J.D. Lawson, The Physics of Charged Particle Beams, $2^{\text {nd }}$ ed. (Clarendon Press, Oxford, 1988), pp. 200.

[10] H. Zhang, Ion Sources, (Science Press, Springer, New York, 1999), pp. 59.

[11] P.M. Lapostolle, IEEE Trans. Nucl. Sci. 18(3), 1101 (1971), https://doi.org/10.1109/TNS.1971.4326292.

[12] M. Ferrario, in: CERN Accelerator School: Plasma Wake Acceleration, (CERN, Geneva, 2014), pp.159-179. http://dx.doi.org/10.5170/CERN-2016-001.159.

[13] V.I. Voznyi, D.P. Shulha, O.O. Drozdenko, M.I. Zakharets, E.A. Mironets, and O.S. Brichenko, Nuclear Physics and Atomic Energy, 18(2), 194-200 (2017). https://doi.org/10.15407/jnpae2017.02.194, (in Russian)

[14] Cold Cathode Penning Ion Source, Model SO-60, http://www.highvolteng.com/media/Leaflets/model_so60 _cold_cathode_penning_ion_source.pdf

\section{СИСТЕМА ВИМІРЮВАННЯ ЕМІТТАНСНИХ ХАРАКТЕРИСТИК ІОННИХ ДЖЕРЕЛ \\ В.І. Возний, М.О. Сайко, О.Г. Пономарьов, С.О. Садовий, О.В. Алексенко, Р.О. Шуліпа \\ Інститут прикладної фізики НАН України \\ 58, вул. Петропавлівська, 40000 Суми, Украӥна}

У статті представлені результати розробки системи вимірювання еміттансних характеристик іонних джерел, досліджуваних в ІПФ НАН України з метою отримання іонних пучків з високою яскравістю. Система вимірювання еміттанса виконана за схемою електростатичного сканера і складається з двох основних частин: сканера, який переміщається в напрямку, перпендикулярному осі пучка за допомогою крокового двигуна, і електронної системи управління, збору і обробки даних. Система управління та обробки даних містить мікрокомп'ютер Raspberry pi 3В, прецизійні ЦАП/АЦП, високовольтний 
підсилювач для генерування напруги \pm 500 В на відхиляючих пластинах сканера, широкодиапазонний інтегратор струму. Визначення еміттанса полягає у вимірюванні розподілу інтенсивності іонного пучка при переміщенні сканера по координаті $x$ i електростатичному скануванні по куту $x^{\prime}$. Отриманий двовимірний масив даних дозволяє визначити основні еміттансні характеристики іонного пучка: геометричний $90 \%$ еміттанс, середньоквадратичний еміттанс, параметри Твісса і рівняння фазового еліпса середньоквадратичного еміттанса, профіль струму пучка і розподіл щільності струму по куту. Для перевірки працездатності і функціональності вузлів системи були проведені вимірювання еміттансних характеристик іонного джерела пеннінговского типу. Робочим газом був гелій, енергія пучка змінювалася в межах 7-15 кеВ. При енергії пучка 13 кеВ отримані наступні величини еміттанса пучка іонів $\mathrm{He}^{+}$: $90 \%$ еміттанс дорівнює $30 \pi$ 'мм'мрад, середньоквадратичний еміттанс дорівнюе 8,4 мм·мрад, величина нормалізованого середньоквадратичного еміттанса становить 0,022 мм-мрад. Дана система вимірювання еміттанса іонних пучків характеризується малим часом проведення вимірювання, що становить $10-15$ хв.

КЛЮЧОВІ СЛОВА: іонний пучок, електростатичний сканер, функція розподілу Гаусса, середньоквадратичний еміттанс, нормалізований еміттанс, параметри Твісса, пеннінговскє джерело іонів.

\section{СИСТЕМА ИЗМЕРЕНИЯ ЭМИТТАНСНЫХ ХАРАКТЕРИСТИК ИОННЫХ ИСТОЧНИКОВ \\ В.И. Возный, Н.А. Сайко, А.Г. Пономарев, С.А. Садовой, О.В. Алексенко, Р.А. Шулипа.}

Институт прикладной физики НАН Украины

58, ул. Петропавловская, 40000 Сумы, Украина

В статье представлены результаты разработки системы измерения эмиттансных характеристик ионных источников, исследуемых в ИПФ НАН Украины с целью получения ионных пучков с высокой яркостью. Система измерения эмиттанса выполнена по схеме электростатического сканера и состоит из двух основных частей: сканера, который перемещается в направлении, перпендикулярном оси пучка с помощью шагового двигателя, и электронной системы управления, сбора и обработки данных. Система управления и обработки данных содержит микрокомпьютер Raspberry pi 3В, прецизионные ЦАП/АЦП, высоковольтный усилитель сканирующего напряжения до \pm 500 В на отклоняющих пластинах сканера, широкодиапазонный интегратор тока. Определение эмиттанса состоит в измерении распределения интенсивности ионного пучка при перемещении сканера по координате $x$ и электростатическом сканировании по углу $x^{\prime}$. Полученный двумерный массив данных позволяет определить основные эмиттансные характеристики ионного пучка: геометрический $90 \%$ эмиттанс, среднеквадратичный эмиттанс, параметры Твисса и уравнение фазового эллипса среднеквадратичного эмиттанса, профиль тока пучка и распределение плотности тока по углу. Для проверки работоспособности и функциональности узлов системы проведены измерения эмиттансных характеристик ионного источника пеннинговского типа. Рабочим газом являлся гелий, энергия пучка изменялась в пределах 7-15 кэВ. При энергии пучка 13 кэВ получены следующие величины эмиттанса пучка ионов $\mathrm{He}^{+}: 90 \%$ эмиттанс равен $30 \pi \cdot$ мм'мрад, среднеквадратичный эмиттанс равен 8,4 мм·мрад, нормализованный среднеквадратичный эмиттанс составляет 0,022 мммрад. Данная система измерения эмиттанса ионных пучков характеризуется малым временем проведения измерения, составляющим 10-15 мин.

КЛЮЧЕВЫЕ СЛОВА: ионный пучок, электростатический сканер, функция распределения Гаусса, среднеквадратичный эмиттанс, нормализованный эмиттанс, параметры Твисса, пеннинговский источник ионов. 